\title{
Critical success factors of a business tourism destination: Supply side analysis
}

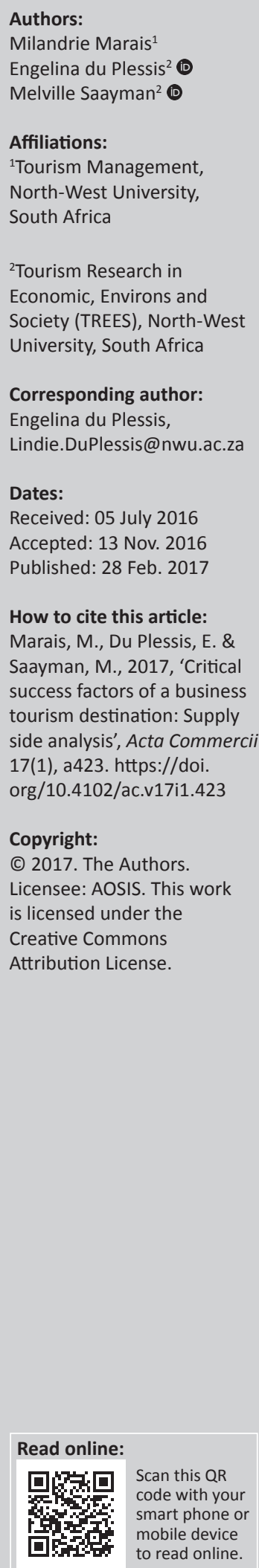

Orientation: Globally, destinations offer various products and services to visitors featuring different attributes and characteristics, making each destination unique. The critical success factors (CSFs) of each of these destinations may differ, making the management process more complex.

Research purpose: The purpose of this research was to identify the CSFs for business tourism destinations in South Africa from a supply viewpoint.

Motivation for the study: Because of the importance of CSFs, many previous studies have attempted to identify such factors within the tourism industry, but few concentrated on business tourism, especially in South Africa, leaving a gap in terms of knowledge. By means of identifying and understanding what these factors are for South Africa, the country could further develop its tourism sector, which could result in its being more competitive as a destination.

Research design, approach and method: To achieve this goal, a qualitative research approach was followed by interviewing seven key business tourism coordinators in South Africa, to determine the key success factors of the business. The data gathered were transcribed and analysed using Creswell's six steps in data analysis and interpretation.

Main findings: Finances, human resources, product and customer-related aspects were identified as the CSFs for business tourism in South Africa.

Practical/managerial implications: Educating the market and marketing value add-ons were identified as important for enhancing and making business tourism in South Africa more competitive.

Contribution/value-add: The results could guide managers in the implementation of effective key success factors in an effort to mitigate management problems in a very competitive sector.

\section{Introduction}

Destinations are complex in nature (Howie 2003:1; Thomas, Shaw \& Page 2011:969) and can be defined as geographical areas containing a variety or amalgam of tourism products, facilities and services, which attract tourists to visit the destination and satisfy their demand by offering an integrated experience (Buhalis 2000:97; Durasevic 2015:84; Gunn 1994:47; Kozak \& Baloglu 2011:9; Leiper 1995:87).

South Africa is part of this competitive environment, offering different products and services. If these products and services are managed correctly, competitive advantage can be gained in this situation. In the year 2015, 15051826 foreign travellers entered South Africa (Statistics South Africa 2015:7), each for different purposes and with varying needs and motivations. The most important reasons for tourists traveling to South Africa in 2015 were for holiday purposes (93.8\%), followed by business and work purposes (4.8\%) (Statistics South Africa 2015:30). These tourists represent an essential source of income for South Africa and especially for the tourism industry, making it very important to keep tourists loyal to the destination and attract even more foreigners to the country.

South Africa's business tourism sector forms part of and contributes to the wider economy of business tourism in Africa and should be exploited to gain more benefits from its growth (Rogerson 2015a:188). Amongst other advantages, such tourists spend more money than other tourists (Dwyer 2002:25; Wan 2011:130), leading to an increased economic impact. This alone is reason enough to ensure the growth of business tourism in South Africa. More and more destinations realise the opportunity which business travel and tourism offer in terms of being competitive as a destination, so that this sector has become an important part of what destinations 
have to offer (Gustafson 2012:276; Smith \& Garnham 2006:3). Nearly 20 years ago, it was noted that 'one of the most important aspects of travel in Africa is related to business purposes' (Dieke 1998:39) and this is still the stance (Christie et al. 2013:55), yet this sector of tourism has not been researched to the same extent as other tourism sectors (Celuch \& Davidson 2009; Rogerson 2015a:184; Stetic \& Simicevic 2010:99). To capitalise on the growth of business tourism in South Africa, it is also important to focus research approaches towards this sector.

The purpose of this research is consequently to investigate the critical success factors (hereafter referred to as CSFs) for business tourism destinations in South Africa from a supply viewpoint. Through identifying and understanding what these CSFs are, more business tourists might be attracted to South Africa, which could impact on the competitiveness and sustainability of the business tourism sector of this country as a destination. Therefore, this article contributes to the existing literature on this sector by identifying the CSFs for business tourism destinations in South Africa from the supply side.

\section{Literature review}

Business tourism is described by researchers as a cross section of industries and businesses and an interaction between stakeholders to meet the needs and everyday requirements of business travellers (Coltman 1989:88; Cook, Yale \& Marqua 2010:4, 14; Faulconbridge et al. 2009:296; Saayman 2009:2). Business tourism includes all trips related to a traveller's employment or business interests; frequently, the reason for business travel is to attend business events such as conferences and meetings, exhibitions and trade fairs, incentive travel and corporate hospitality events (BTP 2005, as cited by Haven-Tang, Jones \& Webb 2007:109; Mair 2010:178). Many terms are used synonymously for business tourism and business events, including MICE (meetings, incentives, conferences, exhibitions) events, the meetings segment, MCE (meetings, convention, and exhibitions) and the convention or conference industry (Ismail, Yusoff \& Rahman 2014:2; Locke 2010:210). There is also some ambiguity about the use of the word 'meetings', since it might refer to a type of business event but is sometimes used to represent the whole business tourism sector (e.g. meetings industry) (Craven \& Golabowski 2001:5; Sperstad \& Cecil 2011:315).

Growth in business tourism, both domestic and international, has been recorded over the last few decades to an extent where it accounts for $25 \%$ of all tourism in some destinations (Christie et al. 2013:55; Ladkin 2006:62). Although tourism of this type (including business and work purposes) only represented $4.8 \%$ of visits to South Africa in 2015, it has been identified as a growth area within the National Tourism Sector Strategy (Department of Tourism 2011:viii; Statistics South Africa 2015:30).

Literature relating to the history of this sector indicates that some of the initial limitations were politically related, but that after South Africa's new democracy and reintegration into the international economy, tourist arrivals, particularly for business purposes, increased (Rogerson \& Visser 2006:201). Another limitation was the lack of adequate resources and facilities (Burger \& Saayman 2009:16). In earlier years, government did not recognise the contribution that business tourism could make to the country's economy and was therefore unwilling to invest in the development of related infrastructure (Rogers 2003:14). However, South Africa has become an important destination, particularly for regional business travellers (Rogerson 2014:394), so much so that in 2006 South Africa ranked as the eighteenth most popular meeting country in the world based on a forecast considering the number of events scheduled at that point to take place between 2005 and 2016 (Costa 2006:60). This flourishing in the industry can be credited to several factors, such as:

policy documents produced to support national government initiatives; improved accommodation; world-class infrastructure; improvements in air and land connectivity between South Africa and other destinations; the transformation of many South African companies into 'multinational' enterprises with operations in several African countries; Johannesburg's role as a linking global city hosting a cluster of headquarters offices or regional African offices for companies with operations spread across Africa; South Africa's infrastructure for hosting business events; enhanced telecommunication linkages and internet connectivity making travel bookings easier and accessibility of foreign exchange of other countries

which has proven to have a more positive impact than ever before (South African Tourism 2007, as cited by Rogerson 2015a:188). The business tourism sector in South Africa has developed to a point where it provides cost-competitive options and ample leisure, recreation and hospitality opportunities (Department of Tourism 2011:9). South Africa also boasts an excellent track record in hosting international events such as COP17, the 5th BRICS Summit and the World Economic Forum, to name but a few (South African National Convention Bureau [SANCB] 2016). Furthermore, studies indicate that the country's major metropolitan areas face growing competition to attract high-revenueyielding tourists (Rogerson 2013, as cited in Rogerson 2015a:188).

The steady growth in South Africa's business tourism is beneficial to the country, considering that business tourists spend more money on average than leisure tourists - about twice as much per day as other tourists would spend (Dwyer 2002:25; Wan 2011:130; Swarbrooke \& Horner 2001, as cited by Rogers 2013:30); they are not as bound to peak seasons as is the case with leisure tourists; business takes place throughout the year, so that business tourists can smooth out seasonality problems (Rogers 2003:23, 2013:76). These tourists firstly attend to business matters, as per the purpose of the trip, and secondly sometimes enjoy leisure time afterwards thus acting as a catalyser for the short-break leisure market (Haven-Tang et al. 2007:109). Given that business tourists often travel together, this minimises congestion and pollution, 
leading to business tourism being considered a lower impact tourism type (Locke 2010:211). According to the literature, benefits for the host community and destination can be summarised as follows (Dinovic 2010:17, 22; Fenich 2012:13; Haven-Tang et al. 2007:109; Ramgulam, RaghunandanMohammed \& Raghunandan 2012:69; Sperstad \& Cecil 2011:314; Wan 2011:130): decreased seasonality within a destination, increased level of profitability of a destination, more rational distribution of income, increased creation of jobs in destination, spending by visitors is beneficial to the destination, businesses within the destination can receive earnings in foreign currency, stimulation of locals in the community may lead to developed interest in international trends, cultural heritage could be strengthened and promoted by the community, creation of a sense of pride within the community, enhanced destination image, business events may catalyse short-break leisure, and infrastructural and social development is encouraged in the area.

Keeping all these benefits of business tourism in mind, it becomes apparent that it is important to undertake research in this sector in order to develop and manage this sector within the tourism industry. By doing so, South Africa as a destination has an opportunity to capitalise on all the related benefits.

Previous studies on business tourism have found that management is of importance for competitiveness and sustainability (Burger \& Saayman 2009:16; Ramgulam et al. 2012:71). Furthermore, strategic management is about the management of the big picture, ensuring a more competitive fit between an organisation, or, in this case, a sector, and its changing environment (Cassidy \& Kreitner 2011:264). Identifying CSFs has become an important concept in strategic management (Grunert \& Ellegaard 1993:246, 249; Ketelhohn 1998:339; Nieh \& Pong 2012:424). CSFs, key success factors (KSF), key result areas (KRA), strategic factors, limited factors, or strategic variables (Engelbrecht, Kruger \& Saayman 2014:239; Nieh \& Pong 2012:424), usually indicated by literature to comprise of three to 10 aspects (combinations of activities and processes) that must perform or be performed well in order to ensure success, attain the goals of management and ensure competitive performance (Avcikurt, Altay \& Ilban 2011:153; Boynton \& Zmud 1984:17; Brotherton 2004b:20; Brotherton \& Shaw 1996:114; Bullen \& Rockart 1986:385; Engelbrecht, et al. 2014:239; Geller 1985:77; Guynes \& Vanecek 1996:202; Khandelwal 2001:17; Leidecker \& Bruno 1987:333; Rockart 1979b:217; Saayman \& Slabbert 2002:8; Van der Westhuizen 2003:14). These factors can be classified according to tangible physical elements or intangible service elements (Wang \& Hung 2015:93) as: situation or context specific (Geller 1985:78); generic to a given combination of industrial or market or broader environmental conditions (Geller 1985:78; Rockart 1979b:86); short-term (monitoring) and longerterm (building) activities (Rockart 1979a:93); conjunctive or compensatory and perceived or actual CSFs (Grunert \& Ellegaard 1993:258); industry or strategic and operational CSFs (Ketelhohn 1998:338, 340); viewpoints: organisation perspective and user perspective (Lee 1989, as cited by Griffin 1995:327).

Another classification includes sectors: it has been found that the type and nature of the tourism operation influences the CSFs for effective management and that CSFs should be identified for each sector, since it may differ between sectors (Burger \& Saayman 2009:26; De Witt 2006:4; Manners 2011:7). Figure 1 below shows that most of the studies have been conducted in the accommodation sector.

From the literature review, it is also interesting to note that these CSFs can be determined by focussing either on the demand or supply side depending on the focus of the research. From a methodology point of view, the CSFs can also be determined by means of a quantitative approach, qualitative approach or a combination thereof. Most of the studies as listed in Figure 1 were conducted by applying quantitative approach. The most frequently found CSFs identified in the literature review (Figure 1) from a supply were, in order of importance, human resources, effective financial management, customer-related approach, quality services, quality facilities, being effective, good marketing, effective systems and hygiene.

Thus, regardless of the ample studies already carried out on CSFs in the tourism industry, specific research should be performed in the business tourism sector (Burger \& Saayman 2009:26; Coles \& Mitchell 2009:3). After an attempt to discover previous studies on CSFs relating to business tourism, only two studies were found. Haven-Tang et al. (2007) undertook a study on CSFs for business tourism destinations; Burger and Saayman (2009) focused on the CSFs for managing a conference centre. Only the latter study focused on South Africa. The lack of available literature and studies on CSFs for business tourism emphasised the gap and the necessity for further investigation or study. Furthermore, the literature makes it clear that even though Northern business tourism [referring to that in Northern America, Pacific Asia and Europe (Celuch \& Davidson 2009, as cited by Rogerson 2015a:187)] possesses some characteristics which are parallel to those in Southern business tourism, these two areas of tourism display differences too (Rogerson 2015b, as cited in Rogerson 2015a:187); therefore, research should be carried out specifically on Southern business tourism, including that in South Africa.

Amidst the increasing pressure, competition and growth, it is important to understand which CSFs management should focus on. Understanding these factors that can lead to the success of business tourism within South Africa can improve the industry, leading to the success of individual tourism ventures within the destination, and also boosting the development of South Africa as a business tourism destination. In addition, the growth of South Africa's business tourism can offer entrepreneurs new opportunities in terms of products and services, given the fact that the business tourism sector involves a variety of other sectors and industries (Coltman 1989:88). 
Critical success factors of a business tourism destination

\begin{tabular}{|c|c|c|c|c|c|}
\hline Year & Author & Title & Key success factors & & \\
\hline 1985 & Geller & $\begin{array}{l}\text { Tracking the Critical Success } \\
\text { Factors for Hotel Competencies }\end{array}$ & $\begin{array}{l}\text { Employee attitude } \\
\text { Guest satisfaction (service) } \\
\text { Superior product (physical plant) }\end{array}$ & $\begin{array}{l}\text { Cost control } \\
\text { Increase market share } \\
\text { Increase customer price-value } \\
\text { perception }\end{array}$ & $\begin{array}{l}\text { Superior location } \\
\text { Maximise revenue } \\
\text { Achieve market segmentation }\end{array}$ \\
\hline 1995 & Griffin & $\begin{array}{l}\text { A categorisation scheme for } \\
\text { critical success factors of } \\
\text { lodging yield management } \\
\text { systems }\end{array}$ & $\begin{array}{l}\text { System } \\
\text { User-education }\end{array}$ & $\begin{array}{l}\text { External environment } \\
\text { Organisational support }\end{array}$ & User-traits \\
\hline 1996 & Brotherton and Shaw & $\begin{array}{l}\text { Towards an identification and } \\
\text { classification of critical success } \\
\text { factors in UK hotels plc }\end{array}$ & $\begin{array}{l}\text { Front office } \\
\text { Food and beverage service } \\
\text { Food and beverage production }\end{array}$ & $\begin{array}{l}\text { Back of house } \\
\text { Sales and marketing } \\
\text { Human resource management }\end{array}$ & $\begin{array}{l}\text { Conference and banqueting } \\
\text { Leisure operations } \\
\text { Accounting and control } \\
\text { Guest accommodation }\end{array}$ \\
\hline 1998 & Choon-Chiang & $\begin{array}{l}\text { City clubs in Singapore: } \\
\text { competitor analysis and key } \\
\text { success factors. }\end{array}$ & $\begin{array}{l}\text { Clearly defined image and } \\
\text { character } \\
\text { Quality products - clubhouse, } \\
\text { services and facilities }\end{array}$ & $\begin{array}{l}\text { Member-oriented strategies } \\
\text { Comfortable club area per } \\
\text { member ratio } \\
\text { Responsive to changing needs of } \\
\text { members }\end{array}$ & $\begin{array}{l}\text { Core group of loyal and dedicated } \\
\text { staff } \\
\text { Financial resources or revenues } \\
\text { available }\end{array}$ \\
\hline 1998 & Hansen and Eringa & $\begin{array}{l}\text { Critical success factors in yield } \\
\text { management: a development } \\
\text { and analysis }\end{array}$ & $\begin{array}{l}\text { Top management commitment } \\
\text { Training of employees } \\
\text { Experience of employees } \\
\text { Recruitment }\end{array}$ & $\begin{array}{l}\text { Organisation of the YM function } \\
\text { Incentive and reward schemes } \\
\text { Communication and } \\
\text { interdepartmental cooperation }\end{array}$ & $\begin{array}{l}\text { Feedback to employees } \\
\text { Development of a yield culture } \\
\text { Employee commitment }\end{array}$ \\
\hline 2003 & Brotherton et al. & $\begin{array}{l}\text { Critical success factors in UK } \\
\text { and Dutch hotels }\end{array}$ & $\begin{array}{l}\text { Front office } \\
\text { Conference \& banqueting } \\
\text { Human resource management } \\
\text { Guest accommodation }\end{array}$ & $\begin{array}{l}\text { Leisure operations } \\
\text { Marketing \& sales } \\
\text { Food \& beverage (production) }\end{array}$ & $\begin{array}{l}\text { Food \& beverage (service) } \\
\text { Back of house operations } \\
\text { Accounting \& control }\end{array}$ \\
\hline 2003 & Getz & $\begin{array}{l}\text { Bidding on events: identifying } \\
\text { event selection criteria and } \\
\text { critical success factors }\end{array}$ & $\begin{array}{l}\text { Have strong partners in the bid } \\
\text { process } \\
\text { Make excellent presentations to } \\
\text { the decision-makers } \\
\text { Treat every bid as a unique } \\
\text { process }\end{array}$ & $\begin{array}{l}\text { Promote the track record of the } \\
\text { community in hosting events } \\
\text { Assist other organisations to } \\
\text { make better bids. }\end{array}$ & \\
\hline 2003 & Van der Westhuizen & $\begin{array}{l}\text { Key success factors for } \\
\text { developing and managing } \\
\text { guesthouses: a case of a } \\
\text { touristic town }\end{array}$ & $\begin{array}{l}\text { The ability to establish and } \\
\text { uphold a high standard of quality } \\
\text { Show courtesy to guests } \\
\text { The ability to give credit where } \\
\text { credit is due } \\
\text { The ability to be self-efficient }\end{array}$ & $\begin{array}{l}\text { The ability to keep promises } \\
\text { The ability to share positive } \\
\text { information freely Services } \\
\text { provided meet the needs of guests } \\
\text { High levels of hygiene is ensured } \\
\text { Facilities provided meet needs of } \\
\text { guests }\end{array}$ & $\begin{array}{l}\text { Guests welcomed in a personal } \\
\text { manner upon arrival } \\
\text { The guesthouse is located in the } \\
\text { right surroundings } \\
\text { It is determined whether } \\
\text { rendered services and facilities } \\
\text { meet the needs of guests }\end{array}$ \\
\hline $2004 a$ & Brotherton & $\begin{array}{l}\text { Critical success factors in UK } \\
\text { corporate hotels }\end{array}$ & $\begin{array}{l}\text { Functional critical success factors } \\
\text { Accounting \& control } \\
\text { Human resource management } \\
\text { Marketing \& sales }\end{array}$ & $\begin{array}{l}\text { Departmental critical success } \\
\text { factors } \\
\text { Food \& Beverage (Service) } \\
\text { Front office } \\
\text { Back of house }\end{array}$ & $\begin{array}{l}\text { Departmental critical success } \\
\text { factors } \\
\text { Conference and banqueting } \\
\text { Guest accommodation } \\
\text { Leisure options }\end{array}$ \\
\hline 2006 & Getz and Brown & $\begin{array}{l}\text { Critical success factors for wine } \\
\text { tourism regions: a demand } \\
\text { analysis }\end{array}$ & $\begin{array}{l}\text { Core wine product } \\
\text { Core destination appeal }\end{array}$ & $\begin{array}{l}\text { Core cultural product } \\
\text { Variety }\end{array}$ & Tourist-oriented \\
\hline 2004b & Brotherton & $\begin{array}{l}\text { Critical success factors in UK } \\
\text { budget hotel operations }\end{array}$ & $\begin{array}{l}\text { Customer service } \\
\text { Core product } \\
\text { Strategic control }\end{array}$ & $\begin{array}{l}\text { Hygiene and quality } \\
\text { Consistency }\end{array}$ & $\begin{array}{l}\text { Pricing } \\
\text { Location }\end{array}$ \\
\hline 2006 & Li et al. & $\begin{array}{l}\text { The importance and } \\
\text { performance of key success } \\
\text { factors in international joint } \\
\text { venture hotels in China }\end{array}$ & $\begin{array}{l}\text { Financial support } \\
\text { Marketing strategic planning }\end{array}$ & $\begin{array}{l}\text { Information exchange } \\
\text { Performance review }\end{array}$ & \\
\hline 2007 & Haven-Tang et al. & $\begin{array}{l}\text { Critical success factors for } \\
\text { business tourism destinations }\end{array}$ & $\begin{array}{l}\text { Leadership } \\
\text { Networking } \\
\text { Branding }\end{array}$ & $\begin{array}{l}\text { Networking } \\
\text { Skills } \\
\text { Ambassadors }\end{array}$ & $\begin{array}{l}\text { Infrastructure } \\
\text { Bidding }\end{array}$ \\
\hline 2007 & Pikkemaat and Schuckert & $\begin{array}{l}\text { Success factors of theme parks - } \\
\text { an exploratory study }\end{array}$ & $\begin{array}{l}\text { Quality } \\
\text { Safety and security }\end{array}$ & $\begin{array}{l}\text { Multivarious range of emotions } \\
\text { and attractions } \\
\text { Emotions }\end{array}$ & $\begin{array}{l}\text { Functionality and infrastructure } \\
\text { Branding }\end{array}$ \\
\hline 2007 & DiPietro et al. & $\begin{array}{l}\text { Multi-unit management key } \\
\text { success factors in the casual } \\
\text { dining restaurant industry }\end{array}$ & $\begin{array}{l}\text { Single unit operations } \\
\text { Standard operating procedures } \\
\text { Multi-unit strategic planning }\end{array}$ & $\begin{array}{l}\text { Interpersonal and social } \\
\text { responsibilities Travel and visiting } \\
\text { units }\end{array}$ & $\begin{array}{l}\text { Human relations } \\
\text { Unit level finances }\end{array}$ \\
\hline 2008 & Camillo, Connolly and Kim & $\begin{array}{l}\text { Critical success factors for } \\
\text { independent restaurants }\end{array}$ & $\begin{array}{l}\text { Create and articulate a clear, } \\
\text { well-crafted, and well-researched } \\
\text { vision and business plane } \\
\text { Stay focused } \\
\text { Allocate resources appropriately } \\
\text { and consistently to execute the } \\
\text { vision and plan }\end{array}$ & $\begin{array}{l}\text { Concepts must be viable and } \\
\text { distinct in the marketplace } \\
\text { Convenient location with } \\
\text { sufficient demand generators } \\
\text { Competent employees and } \\
\text { management }\end{array}$ & $\begin{array}{l}\text { Manage and control business } \\
\text { Maintain an appropriate balance } \\
\text { between food costs and labour } \\
\text { costs } \\
\text { Manage employee turnover } \\
\text { Focus on food and service quality } \\
\text { and consistency }\end{array}$ \\
\hline 2009 & Burger and Saayman & $\begin{array}{l}\text { Key success factors in managing } \\
\text { a conference centre in } \\
\text { South Africa }\end{array}$ & $\begin{array}{l}\text { Activities and layout } \\
\text { Marketing } \\
\text { Core operational aspects }\end{array}$ & $\begin{array}{l}\text { Planning } \\
\text { Design and evaluation }\end{array}$ & $\begin{array}{l}\text { Well trained employees (human } \\
\text { resources) }\end{array}$ \\
\hline 2009 & Hua, Chan and Mao & $\begin{array}{l}\text { Critical success factors and } \\
\text { customer expectation in budget } \\
\text { hotel segment - a case study of } \\
\text { China }\end{array}$ & $\begin{array}{l}\text { From industry professional } \\
\text { Guest safety and security, Guest } \\
\text { bedroom comfort level, Hygiene } \\
\text { and cleanliness, Convenient } \\
\text { locations } \\
\text { Speed of guest service }\end{array}$ & $\begin{array}{l}\text { According to hotel investor } \\
\text { Strong brand differentiation, } \\
\text { Central sales/reservation system, } \\
\text { Geographic coverage of hotel } \\
\text { network, Value for money } \\
\text { accommodation } \\
\text { Guest bedroom comfort level }\end{array}$ & $\begin{array}{l}\text { From government authority } \\
\text { Strong brand differentiation, } \\
\text { Guest safety and security, Value } \\
\text { for money accommodation, } \\
\text { Guest bedroom comfort level, } \\
\text { Speed of guest service } \\
\text { According to customer } \\
\text { experience } \\
\text { Service quality, Physical product, } \\
\text { Promotion } \\
\text { Location, Price }\end{array}$ \\
\hline
\end{tabular}

$\mathrm{QM}$, quality management; SME, small and medium enterprise; NGO, non-governmental organization; YM, Yield management.

Source: Marais 2016

FIGURE 1: Previous published studies on critical success factors. 
Critical success factors of a business tourism destination

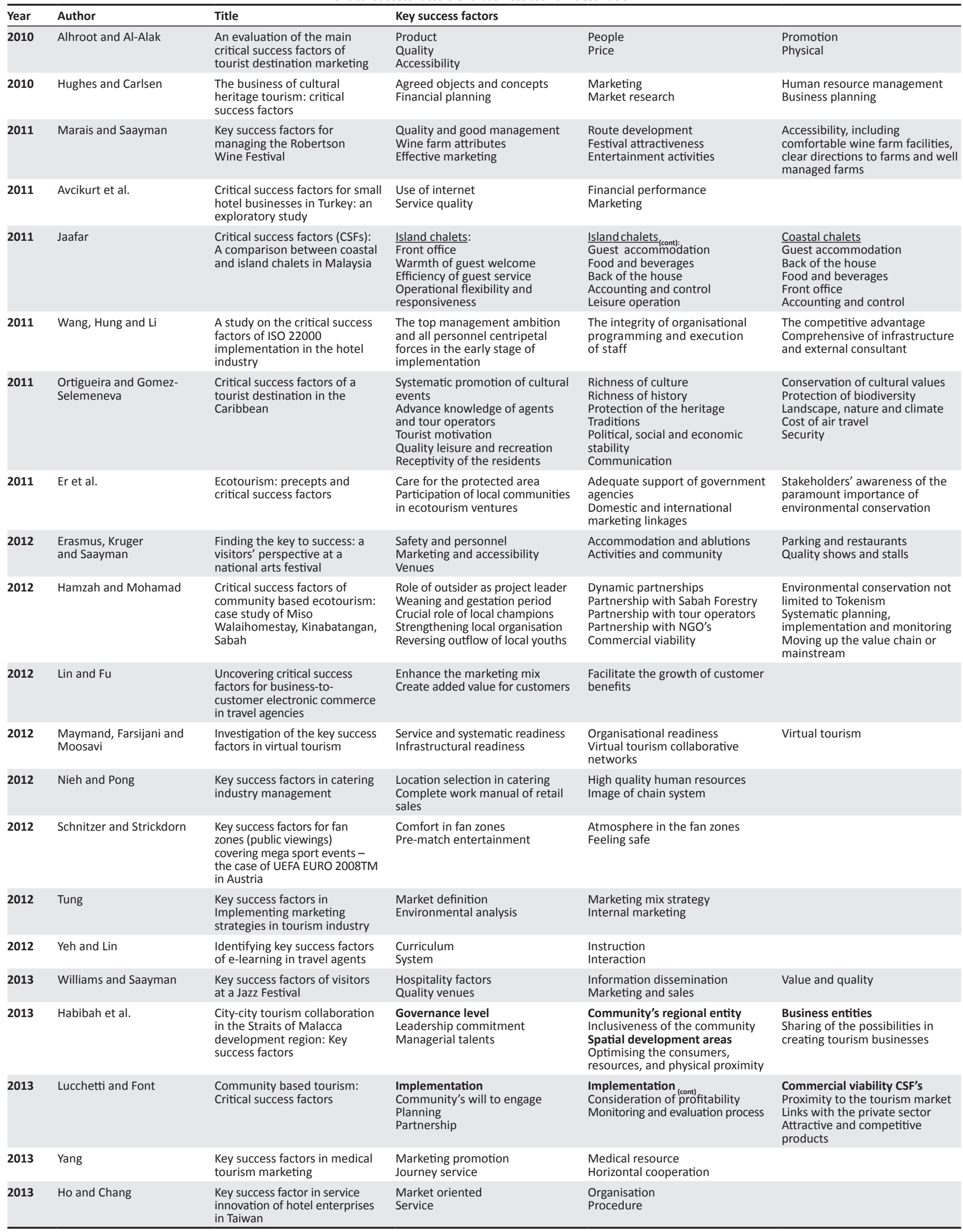

$\mathrm{QM}$, quality management; SME, small and medium enterprise; NGO, non-governmental organization; YM, Yield management.

Source: Marais 2016

FIGURE 1 (Continues...): Previous published studies on critical success factors. 
Critical success factors of a business tourism destination

\begin{tabular}{|c|c|c|c|c|c|}
\hline Year & Author & Title & Key success factors & & \\
\hline 2013 & Hung & $\begin{array}{l}\text { The key success factors on the } \\
\text { customer relationship } \\
\text { management system in travel } \\
\text { agencies }\end{array}$ & Organisational & Technology & Function \\
\hline 2014 & $\begin{array}{l}\text { Manners, Saayman } \\
\text { and Kruger }\end{array}$ & $\begin{array}{l}\text { Managing a live music } \\
\text { performance: A supply-side } \\
\text { analysis }\end{array}$ & $\begin{array}{l}\text { Artist } \\
\text { Audience expectation and } \\
\text { satisfaction }\end{array}$ & $\begin{array}{l}\text { Marketing and media } \\
\text { Technical aspects }\end{array}$ & \\
\hline 2014 & Engelbrecht et al. & $\begin{array}{l}\text { An analysis of critical success } \\
\text { factors for managing the } \\
\text { tourist experience at Kruger } \\
\text { National Park }\end{array}$ & $\begin{array}{l}\text { General management } \\
\text { Wildlife experience } \\
\text { Facilities }\end{array}$ & $\begin{array}{l}\text { Green management } \\
\text { Leisure and hospitality facilities } \\
\text { Interpretation }\end{array}$ & $\begin{array}{l}\text { Variety activities } \\
\text { Accommodation facilities } \\
\text { Luxuries }\end{array}$ \\
\hline 2014 & Du Plessis et al. & $\begin{array}{l}\text { Key success factors in } \\
\text { managing a visitors' experience } \\
\text { at a South African international } \\
\text { airport }\end{array}$ & $\begin{array}{l}\text { Physical comfort } \\
\text { Amenities }\end{array}$ & $\begin{array}{l}\text { Visitor facilities } \\
\text { Passenger services }\end{array}$ & Accessibility \\
\hline 2014 & Campiranon and Scott & $\begin{array}{l}\text { Critical success factors for crisis } \\
\text { recovery management: a case } \\
\text { study of Phuket hotels }\end{array}$ & $\begin{array}{l}\text { Crisis management plan } \\
\text { Market segmentation }\end{array}$ & $\begin{array}{l}\text { Marketing promotion } \\
\text { Collaboration }\end{array}$ & Personnel management \\
\hline 2014 & Freeman and Thomlinson & $\begin{array}{l}\text { Mountain bike tourism and } \\
\text { community development in } \\
\text { British Columbia: critical } \\
\text { success factors for the future }\end{array}$ & $\begin{array}{l}\text { Contingent factors } \\
\text { Community champions or } \\
\text { stakeholders or political will } \\
\text { Legislation or regulatory or } \\
\text { frameworks } \\
\text { Physical geography or terrain or } \\
\text { trails } \\
\text { Funding sources (Public or private } \\
\text { or in-kind) }\end{array}$ & $\begin{array}{l}\text { Non-contingent factors } \\
\text { Mountain bike clubs or schools } \\
\text { or camps or program } \\
\text { Destination marketing or } \\
\text { management } \\
\text { Infrastructure or amenities or } \\
\text { supporting services } \\
\text { Mountain bike culture or } \\
\text { lifestyle or events }\end{array}$ & \\
\hline 2014 & Campos et al. & $\begin{array}{l}\text { Critical success factors for } \\
\text { total quality culture: A } \\
\text { structural model }\end{array}$ & $\begin{array}{l}\text { Leadership } \\
\text { Empowerment }\end{array}$ & $\begin{array}{l}\text { Info/Communication } \\
\text { Total quality culture }\end{array}$ & \\
\hline 2014 & $\begin{array}{l}\text { De Witt, Van der Merwe } \\
\text { and Saayman }\end{array}$ & $\begin{array}{l}\text { Critical ecotourism factors } \\
\text { applicable to national parks: } \\
\text { a visitor perspective }\end{array}$ & $\begin{array}{l}\text { Product development } \\
\text { Local community involvement }\end{array}$ & $\begin{array}{l}\text { Environmentally friendly practices } \\
\text { Food and activities }\end{array}$ & $\begin{array}{l}\text { Ethical behaviour } \\
\text { Policies }\end{array}$ \\
\hline 2015 & Jones et al. & $\begin{array}{l}\text { Determining the critical success } \\
\text { factors of the wine tourism } \\
\text { region of Napa from a supply } \\
\text { perspective }\end{array}$ & $\begin{array}{l}\text { Product } \\
\text { Lifestyle }\end{array}$ & $\begin{array}{l}\text { Embracing tourism } \\
\text { Branding } \\
\text { Land protection }\end{array}$ & $\begin{array}{l}\text { Entrepreneurs/individual } \\
\text { Partnerships } \\
\text { Community involvement and } \\
\text { support }\end{array}$ \\
\hline 2015 & Mardani et al. & $\begin{array}{l}\text { A combined hybrid fuzzy } \\
\text { multiple criteria decision- } \\
\text { making approach to evaluating } \\
\text { of QM critical success factors in } \\
\text { SME's hotels firms }\end{array}$ & $\begin{array}{l}\text { Main factors } \\
\text { Human } \\
\text { Organisational factors }\end{array}$ & $\begin{array}{l}\text { Technological factors } \\
\text { Leadership } \\
\text { Employee empowerment }\end{array}$ & Teamwork \\
\hline 2015 & Ferreira and Fernandes & $\begin{array}{l}\text { Identification of critical } \\
\text { success factors that maximise } \\
\text { customers' satisfaction: } \\
\text { multivariate analysis }\end{array}$ & $\begin{array}{l}\text { Pricing strategy and free services } \\
\text { Loyalty } \\
\text { Image }\end{array}$ & $\begin{array}{l}\text { Supply and stock } \\
\text { Information } \\
\text { Logistics }\end{array}$ & Virtual channels \\
\hline 2015 & Wang and Hung & $\begin{array}{l}\text { Customer perceptions of } \\
\text { critical success factors for } \\
\text { guest houses }\end{array}$ & $\begin{array}{l}\text { Home atmosphere } \\
\text { Room facilities }\end{array}$ & $\begin{array}{l}\text { Location } \\
\text { Cleanliness }\end{array}$ & Value for money \\
\hline 2015 & Mohamed & $\begin{array}{l}\text { Exploring the critical success } \\
\text { factors (CSF) and limitations of } \\
\text { enterprise resource planning } \\
\text { (ERP) systems: The case of } \\
\text { Egyptian hotels }\end{array}$ & $\begin{array}{l}\text { Appropriate ERP consultants } \\
\text { Avoidance of software of changes }\end{array}$ & $\begin{array}{l}\text { Training \& educating employees } \\
\text { Confirmation of finalised solutions }\end{array}$ & Teamwork for the ERP project \\
\hline
\end{tabular}

QM, quality management; SME, small and medium enterprise; NGO, non-governmental organization; YM, Yield management.

Source: Marais 2016

FIGURE 1 (Continues...): Previous published studies on critical success factors.

\section{Method of research}

In order to identify the CSFs for South Africa as a business tourism destination, a qualitative survey comprising seven interviews was conducted between January and March 2016. In order to obtain inputs from all areas of the said sector, interviews were conducted with business tourism coordinators from different kinds of organisations including ICC (international convention centre), hotels with conference centres, PCOs (professional conference organisers) and event organising companies. Respondents also represented a variety of destinations across South Africa. The seven respondents were selected by contacting organisations who are listed as conference venues or conference organisers in the Meetings Guide 2014 of South Africa and were thereafter selected based on their willingness to participate. An attempt was made to schedule interviews with prospective respondents by sending e-mails. However, no responses were received. A second attempt included direct telephonic communication. Six interviews took place telephonically. A seventh interview was performed one-on-one with a representative from an organisation close enough to access. Data saturation was reached at this point, after similar answers were received from multiple respondents.

Structured interviews were utilised to collect the data for this study. Such interviews, within the qualitative research method, are usually employed in multiple case studies to ensure structure and also to make sure that the questions are detailed and developed in advance as, for example, in survey research (Nieuwenhuis 2008:87). The first four questions were designed to obtain a general but basic profile of each respondent, followed by questions designed to establish the respondents' opinions on South Africa's business tourism sector as well as the related CSFs. Based on the responses, follow-up questions were formulated respectively. 
Interviews were audiotaped, transcribed and subsequently further studied by the researcher.

Results from an in-depth literature review as indicated in Figure 1 (Marais \& Saayman 2011:149; Nieh \& Pong 2012:424; Witbooi, Cupido \& Ukpere 2011:1937) were utilised to compile the interview guideline. This consisted of three sections:

Section A comprised the demographic profile, which focused mainly on the respondent and his/her organisation. This was to determine the respondent's job title, location of the organisation, type of organisation and the average size of a typical event planned by the relevant organisation.

Section B was structured to obtain the respondent's opinion on South Africa as a business tourism destination. Questions referred to enhancing South Africa as such a destination and making the industry more competitive and sustainable.

Section C focused on CSFs and determining the respondents' opinions on those CSFs applicable for their organisation.

Collected data were transcribed into text and presented in narrative form, after which the material was analysed using Creswell's six steps in data analysis and interpretation (Creswell 2009:185-189):

- Organise and prepare the data.

- Read through all the data.

- Begin a detailed analysis with a coding process: The data with regard to South Africa's business tourism sector as well as the CSFs identified were coded in order to identify the important aspects. Thereafter, a recoding process was followed by the consulting academics familiar with research on CSFs in order to ensure trustworthiness. The results were then compared with one another in order to derive an overall perspective.

- Use the coding process to generate a description of the setting or people as well as categories or themes for analysis: The various codes were then divided into categories, whereafter themes were allocated to each category. The allocated themes appear as one of the major findings in the results.

- Represent the data (description and themes) in the research report.

- A final step in data analysis involves arriving at an interpretation, or meaning of, the data.

Trustworthiness is an indication of methodological soundness and adequacy (Holloway \& Wheeler 2002:254). For this research, trustworthiness was accomplished by means of coding and recoding the data.

\section{Results}

Based on the survey, the following results were found.

\section{Demographic profiles}

Section A focused on the demographic profile of the respondent and his or her organisation. Four questions were asked to obtain this profile. The findings of Section A are summarised in Table 1.

Table 1 lists the different job titles of each respondent; even though their titles differ, all of them are involved in the coordinating of business tourism. All respondents have been employed within the organisation for a significant period of time (more than 5 years) which indicates a degree of experience and knowledgeableness about the industry. Businesses were predominantly located in the Free State, Gauteng, KwaZulu-Natal, Western Cape and Eastern Cape. Respondents are employed at different kinds of organisations such as hotels, conference centre and spas, hotel and conference centres, events management companies, PCOs and convention centres. The sizes of the events that the respondents are associated with vary from as few as 50 attendees to as many as 1200 .

\section{Enhancing the competitiveness of South Africa as a business tourism destination}

Respondents were asked what could be done to enhance business tourism and make South Africa more competitive as a destination. Two aspects were frequently mentioned. One of the activities most respondents (B, C, D, F) referred to was educating the market and providing sufficient information that could aid in decision-making when choosing a business destination product. This was motivated by Respondent $C$ who said that one should 'provide more information so that potential clients and visitors have sufficient information. This will help them make decisions on where to go and what to do'. A second aspect that was frequently mentioned was offering value add-on products and services (A, B, D). Respondent B explained it in this way, '...if they're going to be coming all this way for a conference, then they're going to be doing add-ons as well...'. From the interviews, aspects such as the flights being more numerous and more competitive $(E, F, G)$, security or safety or corruption issues $(C, E, G)$, sorting out of visa matters $(\mathrm{G})$, offering good rates to

TABLE 1: Demographic profiles of respondents and their organisations.

\begin{tabular}{|c|c|c|c|c|c|c|c|}
\hline Variable & Respondent A & Respondent B & Respondent C & Respondent D & Respondent E & Respondent F & Respondent G \\
\hline Job title & $\begin{array}{l}\text { Food \& beverage } \\
\text { manager }\end{array}$ & $\begin{array}{l}\text { Corporate sales \& } \\
\text { marketing manager }\end{array}$ & Director of the company & $\begin{array}{l}\text { Destinations } \\
\text { management } \\
\text { consultant }\end{array}$ & Event coordinator & $\begin{array}{l}\text { Sales \& marketing } \\
\text { manager }\end{array}$ & $\begin{array}{l}\text { Owner of the } \\
\text { company }\end{array}$ \\
\hline $\begin{array}{l}\text { Location of } \\
\text { organisation }\end{array}$ & Free State & Gauteng & Gauteng & KwaZulu-Natal & Western Cape & KwaZulu-Natal & Eastern Cape \\
\hline $\begin{array}{l}\text { Type of } \\
\text { organisation }\end{array}$ & $\begin{array}{l}\text { Hotel, Conference } \\
\text { Centre and Spa }\end{array}$ & $\begin{array}{l}\text { Hotel \& Conference } \\
\text { Centre }\end{array}$ & $\begin{array}{l}\text { Events management } \\
\text { company (government \& } \\
\text { corporate) }\end{array}$ & $\begin{array}{l}\text { Professional } \\
\text { conference organiser } \\
\text { (PCO) }\end{array}$ & $\begin{array}{l}\text { Professional } \\
\text { conference organiser } \\
\text { (PCO) }\end{array}$ & Convention centre & $\begin{array}{l}\text { Conference } \\
\text { management } \\
\text { company }\end{array}$ \\
\hline $\begin{array}{l}\text { Average attendees } \\
\text { at a typical event }\end{array}$ & $60-80$ & $50-100$ & $200-800$ & Up to 1000 & $200-1000$ & 1600 & $250-1200$ \\
\hline
\end{tabular}


tourists (B) and improving client service (A) emerged. Respondent A sounded very positive in stating that:

'...we will have to focus on what we have, expand on that and make it the best we can...we have to focus on what we can add to that experience and the total package.'

From this, it could be deduced that the respondents feel strongly about educating the market about the uniqueness of South Africa as well as all of the add-ons available here that could enhance business tourism in this country.

\section{Critical success factors for business tourism in South Africa}

Respondents were asked what they would list as CSFs relevant for their organisations; this was posed as an open question. After this, a list of the top 10 factors found in the literature review was read, and respondents were asked to indicate what, according to their perception, the five most important ones are. These two questions were aimed to identify which CSFs they regarded as important for business tourism in South Africa.

In the open question, several different factors were named. From the data gathered, four themes were identified that represented the CSFs. Supporting literature is mentioned following each theme or factor. The four themes or factors (not presented in order of importance) are finances (Avcikurt et al. 2011; Brotherton 2004a; Brotherton et al. 2003; Brotherton \& Shaw 1996; DiPietro et al. 2007; Geller 1985; Hughes \& Carlsen 2010; Jaafar 2011), human resources (Brotherton et al. 2003; Brotherton \& Shaw 1996; Burger \& Saayman 2009; Campiranon \& Scott 2014; Choon-Chiang 1998; Geller 1985; Hughes \& Carlsen 2010; Nieh \& Pong 2012), product (Alhroot \& Alalak 2010; Brotherton \& Shaw 1996; Geller 1985; Getz \& Brown 2006; Jones, Singh \& Hsiung 2015; Lin \& Fu 2012; Lucchetti \& Font 2013) and customer-related aspects (Brotherton 2004a, 2004b; Brotherton et al. 2003; Brotherton \& Shaw 1996; Du Plessis, Saayman \& Potgieter 2014; Geller 1985; Jaafar 2011; Lin \& Fu 2012; Van der Westhuizen \& Saayman 2007).

\section{Theme 1: Finances}

The first theme or factor related to finances and included constructs such as sound financial management, maintaining costs and prices, and absorbing increased costs. Respondent $G$ described sound financial management as crucial. Furthermore, Respondent $\mathrm{G}$ explained that when planning a business event, large amounts of money are involved and mistakes cannot be made. Respondent B indicated that costs have to be maintained in order to make a profit and that in the case of an increase in them, they have to be absorbed. Respondent $C$ added that with the unstable Rand, it is important to be able to hold a quoted price. Many researchers have found that finances, or an aspect of finances, are a vital CSF. The issue of finance may differ from one case to the next [accurate financial reporting (Brotherton et al. 2003; Jaafar 2011), achieving accurate costing (Brotherton et al. 2003), charging competitive prices (Brotherton \& Shaw 1996), consideration of profit (Lucchetti \& Font 2013), cost control (Geller 1985), cost of air travel (Ortigueira \& GomezSelemeneva 2011), effective bad debt control procedures and effective revenue or yield management procedures (Brotherton et al. 2003), financial performance (Avcikurt et al. 2011), financial planning (Hughes \& Carlsen 2010), financial support (Li, Wong \& Luk 2006), payment models (Lin \& Fu 2012), pricing (Brotherton 2004a)]. The results from this study differ in identifying different financial aspects such as not altering a quotation, absorbing costs and making a profit amidst an unstable currency. The response of Respondent G, however, includes almost all of the aforementioned aspects within finance as indicated in the literature. Business tourism coordinators should be aware of and understand finances and financial management. It is also important to comprehend the market and the economy and how it functions, how to absorb costs and how to manage large amounts of money as these can all contribute to making a profit.

\section{Theme 2: Human resources}

This theme includes all aspects relating to staff, managing staff, satisfaction of staff, staff knowledge, teamwork, working together, relying on each other, well trained staff and being able to handle an event's attendees. Respondent $\mathrm{B}$ stated that it is important to manage one's staff well and ensure their happiness. Furthermore, the staff members must be knowledgeable about the product. This is supported by previous studies on CSFs (Brotherton 2004b; Campiranon \& Scott 2014; Hughes \& Carlsen 2010). Respondent F added that the event's success is reliant on the staff and that these staff members should be well trained and able to handle attendees, which concurs with Mohamed's (2015) and Burger and Saayman's (2009) findings. Respondent E focussed more on teamwork and indicated that working together, relying on each other and working towards a common goal are important. In addition to those already mentioned, there are many other literature sources that indicate human resources as a significant CSF (Brotherton et al. 2003; Brotherton \& Shaw 1996; Choon-Chiang 1998; Geller 1985; Nieh \& Pong 2012) and point out that staff have to be well managed, well informed and able to work together. The importance of this theme was also evident in Section B. Firstly, role-players should strive to work together as a team in order to ensure success. Respondents agree that staff should be knowledgeable about the product, keep up with current trends and come forth with innovative ideas. Although there is considerable negativity associated with labour in South Africa, the country's situation is unique and staff should notice the opportunities provided by this growing sector.

\section{Theme 3: Product}

Most of the responses provided by the respondents relate back to the product itself. The literature indicates that product is an important CSF (Alhroot \& Alalak 2010; Brotherton \& Shaw 1996; Geller 1985; Getz \& Brown 2006; Jones et al. 2015; Lin \& Fu 2012; Lucchetti \& Font 2013). This theme includes constructs such as ensuring that 
arrangements are in place, attention to detail, the different phases of the event, set-ups according to plan and the availability of the product. Respondents A and B indicated that the product and its availability are vital. Respondent E noted that attention to the detail of the event or product is key and that this is important to ensure satisfaction. Brotherton et al. (2003) and Brotherton and Shaw (1996) also identified this specific construct in their respective studies. Respondent $\mathrm{F}$ mentioned various constructs, including being ready for the different phases of the event or product, set-ups being carried out according to plan, food according to expected standards and equipment that is working. Respondent $\mathrm{G}$ contributed to this theme by stating that it is important to ensure that timelines are sound and that all aspects are in place as they should be. From this study, it is evident that the product, in this case the business events, must be available, well-planned, attention given to details and that all aspects are in place.

\section{Theme 4: Customer-related aspects}

The literature reports that customer-related aspects are important (Brotherton 2004a; Brotherton et al. 2003; Van der Westhuizen \& Saayman 2007). Respondent C stated, 'Good customer service is important', while Respondent A added that it is essential to keep to what has been offered and to be ready for the customers. Respondent F was more specific, declaring that delegates should have an easy experience finding their way around the event. Respondent E added a new term related to customer-related aspects: transparency. Respondent E stated,

\footnotetext{
'...you have to be open with them in terms of not being able to make a deadline, getting something wrong, or if a venue is not able to provide the facilities that they wanted. It is better to be transparent with them than trying to hide it and fixing it yourself and then something goes wrong.'
}

However, this is not supported by the literature as it has not been mentioned in previous studies.

After this, respondents were asked to identify their top five CSFs after the following factors were read aloud to them: human resources, finances, customer-related aspects, quality, facilities, effectivity, marketing, systems, hygiene and product. These are the top 10 factors identified through previous studies (Figure 1).

The factors most frequently identified from answers to this question are as follows:

Human resources (identified by Respondents B, C, D, E and G)

Customer-related aspects (identified by Respondents A, D, E, F and G)

Finances (identified by Respondents B, C, D, E and G)

Product (identified by Respondents A, C, D, E and F)

Marketing (identified by Respondents A, C, E and F).

Four of the five factors confirm the results found in the previous open question. Upon considering these two questions collectively, it is evident that human resources, customer-related aspects, finances and product are CSFs for business tourism.

\section{Ensuring sustainable growth for South Africa as a business tourism destination}

When the respondents were asked their opinion of what could be done to ensure sustainable growth for South Africa as a business tourism destination, their answers varied. Once again some respondents focused on external aspects: Respondent G said,

'Everything comes down to making something affordable and accessible and safe. If these three things continue to improve, they will continue to give people the confidence to come to South Africa.'

Respondent C stated that affordable accommodation is important, whereas Respondent D averred that government could provide more education about the industry and make available more opportunities and jobs, which is what Respondent A suggested too. Looking at internal factors, Respondent B said, 'We have to keep on being competitive and come up with innovative ideas and have that hook that will hook people to come here'. Respondent E remarked that they themselves need to keep up with the current trends and 'if we keep ensuring that we do well in every conference we do, people are more likely to keep on returning'. Respondent $\mathrm{F}$ suggested that tourism coordinators try and attract recurring events such as African regional events which could rotate every 4 years.

Literature evidences that growth can take place organically by investing resources to develop new competencies and capabilities and opening up new market opportunities (Thompson \& Martin 2005:505). By managing the main CSFs, namely finances, human resources, product and customer-related aspects, success can be achieved. The answers provided by Respondents B, E and F, coming up with innovative ideas, keeping up with current trends and focusing on recurring events such as African regional events, respectively, are all steps towards developing new competencies and opening up new market opportunities. It is also clear that all the mentioned role-players should be working together to achieve goals and develop this industry.

\section{Findings and implications}

The first finding confirms literature in terms of CSFs for the tourism industry as finances (Brotherton et al. 2003; Geller 1985; Jaafar 2011; Lucchetti \& Font 2013; Ortigueira \& Gomez-Selemeneva 2011), human resources (Brotherton et al. 2003), product (Jones et al. 2015) and customer-related aspects (Du Plessis et al. 2014). Although the study did not indicate the order of importance of these factors, managers could use this as a guideline and successfully apply these CSFs within their organisations. In the future, these CSFs can also be further analysed within a business tourism context to identify specific constructs in order to make the industry 
even more competitive, because a construct in South Africa might differ from those in other destinations.

Secondly, this study confirms the importance of human resources as a CSF within the tourism industry (Brotherton et al. 2003). Constructs such as teamwork, training and skills and working with attendees remain important as staff members within this industry constantly interact with the tourists and attendees. It is recommended that managers should ensure that their staff members are well trained and informed and that they understand what leads to customer satisfaction and to success.

Although the literature considered marketing an aspect over which businesses have control, for example, their internal environment (Saayman 2009:127), finding three contradicts the general view since it seems as though managers consider marketing an external factor because they cannot manage its success. Money is spent on marketing, but managers do not have direct control over its effectiveness and how the efforts will be received. As a result of this, managers consider marketing, as a CSF, to be less important than those aspects that they exercise direct control over. The implication of this finding is that marketing does have an impact on success, as per the definition of CSFs, and that managers should still focus on marketing as a CSF even although they cannot control its results.

The fourth finding highlights that the emphasis on value add-ons in South Africa is greater than it appears in the literature and that organisations to an extent rely on value add-ons to sell their product. The implication is thus that conference organisers should inform potential clients of the value add-on options available and can even include these as part of the product - as though offering a menu of tourism products for tourists to choose from. These might include trips to nature reserves (such as national parks), coastal resorts, museums, Soweto, mountain ranges, leading golf courses and other exciting options. By doing so, the uniqueness and attractiveness of South Africa should become more evident, which could enhance the motivation to travel here and contribute to the competitiveness of the country as a business tourism destination.

\section{Conclusions}

The goal of this study was to determine the CSFs for business tourism in South Africa. This sector is flourishing in South Africa, so that by identifying the related CSFs, the growth might be made sustainable along with the destination being more competitive. Firstly, from the data collected through the interviews, it was evident that finances, human resources, product and customer-related aspects are important for business tourism in South Africa. Secondly, human resources are important within this industry and sector where contact with tourists is essential. Thirdly, the interviews also found that in order to enhance and make South Africa's business tourism more competitive, focus should be placed on educating the market and on marketing the uniqueness of the country along with value add-on options available in South Africa. These could include any attraction and entertainment in South Africa such as national parks, cultural experiences and coastal resorts. Lastly, in addition to the findings, this study also contributed by providing a basis for literature on business tourism in South Africa and could be used in the future to further investigate the gaps and similarities. However, from the respondents who participated, findings were reached which can be used as a starting point for research on CSFs for business tourism in South Africa.

\section{Acknowledgements}

The authors would like to acknowledge outside reviewers of their drafts and the National Research Foundation (NRF) for funding that supported the research.

\section{Competing interests}

The authors declare that they have no financial or personal relationship(s) that may have inappropriately influenced them in writing this article.

\section{Author's contributions}

This research formed part of a master study conducted by M.M. which was supervised by E.d.P. and M.S.

\section{References}

Alhroot, A.H.H. \& Alalak, B.A.M., 2010, 'An evaluation of the main critical success factors of tourist destination marketing', Interdisciplinary Journal of Contemporary Research in Business 1(12), 315-330.

Avcikurt, C., Altay, H. \& Ilban, M.O., 2011, 'Critical success factors for small hote businesses in Turkey: An exploratory study', Cornell Hospitality Quarterly 52(2), 153-164. http://dx.doi.org/10.1177/1938965509341288

Boynton, A.C. \& Zmud, R.W., 1984, 'An assessment of critical success factors', Sloan Management Review 25(4), 17-27.

Brotherton, B., 2004a, 'Critical success factors in UK budget hotel operations', International Journal of Operations \& Production Management 24(9), 944-969. http://dx.doi.org/10.1108/01443570410552135

Brotherton, B., 2004b, 'Critical success factors in UK corporate hotels', The Service IndustriesJourna/24(3),19-42.http://dx.doi.org/10.1080/0264206042000247740

Brotherton, B., Heinhuis, E., Miller, K. \& Medema, M., 2003, 'Critical success factors in UK and Dutch hotels', Journal of Services Research 2(2), 47-78.

Brotherton, B. \& Shaw, J., 1996, 'Towards an identification and classification of critical success factors in UK hotels plc', International Journal Hospitality Management 15(2), 113-135. http://dx.doi.org/10.1016/0278-4319(96)00014-X

Buhalis, D., 2000, 'Marketing the competitive destination of the future', Tourism Management 21, 97-116. http://dx.doi.org/10.1016/S0261-5177(99)00095-3

Bullen, C.V. \& Rockart, J.F., 1986, 'A primer on critical success factors', in C.V. Bullen \& J.F. Rockart (eds.), The rise of managerial computing: The best of the Center for Information System Research, pp. 383-423, Dow Jones-Irwin, Homewood, CA.

Burger, E. \& Saayman, M., 2009, 'Key success factors in managing a conference centre in South Africa', South African Journal for Research in Sport, Physical Education and Recreation 31(2), 15-28. http://dx.doi.org/10.4314/sajrs.v31i2.46320

Camillo, A.A., Connolly, D.J. \& Kim, W.G., 2008, 'Critical success factors for independent restaurants', Cornell Hospitality Quarterly 49(4), 364-380. http://dx.doi.org/ $10.1177 / 1938965508317712$

Campiranon, K. \& Scott, N., 2014, 'Critical success factors for crisis recovery management: A case study of Phuket hotels', Journal of Travel \& Tourism Marketing 31(3), 313-326. http://dx.doi.org/10.1080/10548408.2013.877414

Campos, A.C., Mendes, J.D., Silva, J.A. \& do Valle, P.O., 2014, 'Critical success factors for total quality culture: A structural model', Tourism \& Management Studies 10(1), 7-15.

Cassidy, C.M. \& Kreitner, R., 2011, Principles of management, 12th edn., SouthWestern Cengage Learning, Bangkok.

Celuch, K. \& Davidson, R., 2009, 'Advances in business tourism research', A selection of papers presented at ATLAS Business Tourism Special Interest Group Meetings, Association for Tourism and Leisure Education (ATLAS), Arnhem. 
Choon-Chiang, L., 1998, 'City clubs in Singapore: Competitor analysis and key success factors', Asia Pacific Journal of Tourism Research 3(1), 55-63. http://dx.doi.org/ factors', Asia Pacific Journal of
$10.1080 / 10941669908722008$

Christie, I., Fernandes, E., Messerli, H. \& Twining-Ward, L., 2013, Tourism in Africa: Harnessing tourism for growth and improved livelihoods, The World Bank, Washington, DC

Coles, C. \& Mitchell, J., 2009, Pro poor analysis of the business and conference value chain in Accra: Final report, Overseas Development Institute, London.

Coltman, M.M., 1989, Introduction to travel and tourism: An international approach, Van Nostrand Reinhold, New York.

Cook, R.A., Yale, L.J. \& Marqua, J.J., 2010, Tourism: The business of travel, 4th edn., Pearson Prentice Hall, Upper Saddle River, NJ.

Costa, I., 2006, 'Business tourism conference looks at SA's international position', Southern Africa Conference, Exhibition and Events Guide 26(3), 60.

Craven, R.E. \& Golabowski, L.J., 2001, The complete idiot's guide to meeting and event planning, Alpha Books Pearson Education, New York.

Creswell, J.W., 2009, Research design: Qualitative, quantitative, and mixed methods approach, 3rd edn., Sage, Thousand Oaks, CA.

De Witt, L., 2006, 'Key success factors for managing special events: The case of wedding tourism', Dissertation - MCom, NWU, Potchefstroom.

De Witt, L., Van der Merwe, P. \& Saayman, M., 2014, 'Critical ecotourism factors applicable to national parks: A visitor perspective', Tourism Review Internationa 17, 179-194. http://dx.doi.org/10.3727/154427213X13838418677005

Department of Tourism see South Africa. Department of Tourism.

Dieke, P.U.C., 1998, 'Regional tourism in Africa: Scope and critical issues', in E. Laws, B. Faulkner \& G. Moscardo (eds.), Embracing and managing change in tourism: International case studies, pp. 29-48, Routledge, London.

Dinovic, L., 2010, 'Developmental prospects of MICE tourism in Montenegro', Selective Tourism 5, 17-31.

DiPietro, R.B., Murphy, K.S., Rivera, M. \& Muller, C.C., 2007, 'Multi-unit management key success factors in the casual dining restaurant industry', International Journal of Contemporary Hospitality Management 19(7), 524-536. http://dx.doi.org/ 10.1108/09596110710818275

Du Plessis, L., Saayman, M. \& Potgieter, M., 2014, 'Key success factors in managing a visitors' experience at a South African international airport', Journal of Contemporary Management 11, 510-533.

Durasevic, S., 2015, 'Tourism in Montenegro: A destination management perspective', Tourism Review 63(1), 81-96.

Dwyer, L., 2002, 'Economic contribution of convention tourism: Conceptual and empirical issues', in K. Weber \& K.S. Chon (eds.), Convention tourism: International research and industry perspectives, pp. 21-36, The Haworth Press Inc., New York.

Engelbrecht, W.H., Kruger, M. \& Saayman, M., 2014, 'An analysis of critical success factors for managing the tourist experience at Kruger National Park', Tourism
Review International 17, 237-251. http://dx.doi.org/10.3727/15442721 Review Internation
$4 \mathrm{X} 13910101597120$

Er, A.C., Sivapalan, S., Rahim, M.N., Toriman, M.E., Adam, J.H. \& Buang, A., 2011 'Ecotourism: Precepts and critical success factors', World Applied Sciences Journal 13, 110-113.

Erasmus, J., Kruger, M. \& Saayman, M., 2012, 'Finding the key to success: A visitors' perspective at a national arts festival', Acta Commercii 12(1), 150-172.

Faulconbridge, J.R., Beaverstock, J.V., Derudder B. \& Witlox, F., 2009, 'Corporate ecologies of business travel in professional service firms: Working towards research agenda', European Urban and Regional Science Studies 16(3), 295-308. http://dx.doi.org/10.1177/0969776409104694

Fenich, G.G., 2012, Meetings, expositions, events, and conventions: An introduction to the industry, 3rd edn., Pearson - Prentice Hall, Old Tappan, NJ.

Ferreira, H.P. \& Fernandes, P.O., 2015, 'Identification of critical success factors that maximise customers' satisfaction: Multivariate analysis', Tourism \& Management Studies 11(1), 164-172.

Freeman, R. \& Thomlinson, E., 2014, 'Mountain bike tourism and community development in British Columbia: Critical success factors for the future' Tourism Review International 18, 9-22. http://dx.doi.org/10.3727/15442721 4 X13990420684400

Geller, N., 1985, 'Tracking the critical success factors for hotel competencies', Cornell Hospitality Quarterly 76-81. http://dx.doi.org/10.1177/001088048502500414

Getz, D., 2003, 'Bidding on events: Identifying event selection criteria and critical success factors', Journal of Convention \& Exhibition Management 5(2), 1-24.

Getz, D. \& Brown, G., 2006, 'Critical success factors for wine tourism regions: A demand analysis', Tourism Management 27(1), 146-158. http://dx.doi.org/ 10.1016/j.tourman.2004.08.002

Griffin, R.K., 1995, 'A categorization scheme for critical success factors of lodging yield management systems', International Journal Hospitality Management 14(3/4) 325-338. https://doi.org/10.1016/0278-4319(95)00039-9

Grunert, K.G. \& Ellegaard, C., 1993, 'The concept of critical success factors: Theory and method', in M.J. Baker (ed.), Perspectives on marketing management: Volume 3 , pp. 245-274, John Wiley \& Sons, London.

Gunn, C.A., 1994, Tourism planning: Basics, concepts, cases, 3rd edn., Taylor \& Francis, Washington, DC

Gustafson, P., 2012, 'Managing business travel: Developments and dilemmas in corporate travel management', Tourism Management 33, 276-284. http://dx.doi. org/10.1016/j.tourman.2011.03.006
Guynes, C. \& Vanecek, M.T., 1996, 'Critical success factors in data management' Information and Management 30(4), 201-209. http://dx.doi.org/10.1016/03787206(95)00053-4

Habibah, A., Hamzah, J., Er, A.C., Buang, A., Selvadurai, S. \& Mushrifah, I., 2013, 'City-city tourism collaboration in the straits of Malacca development region: Key success factors', Asian Social Science 9(13), 40-52. http://dx.doi.org/10.5539/ass. v9n13p40

Hamzah, A. \& Mohamad, N.H., 2012, 'Critical success factors of community based ecotourism: Case study of Miso Walaihomestay, Kinabatangan, Sabah', The Malaysian Forester 75(1), 27-40.

Hansen, C.N. \& Eringa, K., 1998, 'Critical success factors in yield management: A development and analysis', Progress in Tourism and Hospitality Research 4 229-244. http://dx.doi.org/10.1002/(SICI)1099-1603(199809)4:3\%3C229::AIDPTH160\%3E3.0.CO;2-P

Haven-Tang, C., Jones, E. \& Webb, C., 2007, 'Critical success factors for business tourism destinations', Journal of Travel \& 'Tourism Marketing 22(3/4), 109-120. tourism destinations', Journal of Travel \& Toun
http://dx.doi.org/10.1300/J073v22n03_09

Ho, C. \& Chang, W., 2013, 'Key success factor in service innovation of hotel enterprises in Taiwan', Pakistan Journal of Statistics 29(5), 725-732.

Holloway, I. \& Wheeler, S., 2002, Qualitative research in nursing, Blackwell, Oxford. Howie, F., 2003, Managing the tourist destination, Continuum, New York.

Hua, W., Chan, A. \& Mao, Z., 2009, 'Critical success factors and customer expectation in budget hotel segment - A case study of China', Journal of Quality Assurance in Hospitality \& Tourism 10, 59-74. http://dx.doi.org/10.1080/ Assurance in Hospitalit
15280080802713702

Hughes, M. \& Carlsen, J., 2010, 'The business of cultural heritage tourism: Critical success factors', Journal of Heritage Tourism 5(1), 17-32. http://dx.doi.org/ 10.1080/17438730903469805

Hung, C., 2013, 'The key success factors on the customer relationship management system in travel agencies', Pakistan Journal of Statistics 29(5), 785-794.

Ismail, M.F., Yusoff, W.Z.W. \& Rahman, I.A., 2014, Identification of critical success factors (CSF's) for MICE event management through two-round Delphi survey, viewed 11 February 2015, from https://www.academia.edu/8102938/Identification_of Critical_Success_Factors_CSFs_for_MICE_Event_Management_through_TwoRound_Delphi_Survey

Jaafar, M., 2011, 'Critical success factors (CSFs): A comparison between coastal and island chalets in Malaysia', Tourism 59(4), 481-496.

Jones, M.F., Singh, N. \& Hsiung, Y., 2015, 'Determining the critical success factors of the wine tourism region of Napa from a supply perspective', International Journal of Tourism Research 7, 261-271. http://dx.doi.org/10.1002/jtr.1984

Ketelhohn, W., 1998, 'What is a key success factor?', European Management Journal 16(3), 335-340. http://dx.doi.org/10.1016/S0263-2373(98)00010-3

Khandelwal, V.K., 2001, 'An empirical study of misalignment between Australian CEOs and IT managers', Journal of Strategic Information Systems 10(1), 15-28. http:// dx.doi.org/10.1016/S0963-8687(01)00040-3

Kozak, M. \& Baloglu, S., 2011, Managing and marketing tourist destinations: Strategies to gain a competitive edge, Routledge, New York.

Ladkin, A., 2006, 'Conference tourism - MICE market and business tourism', in D. Buhalis \& C. Costa (eds.), Tourism business frontiers: Consumers, products and industry, pp. 56-66, Elsevier, Amsterdam.

Leidecker, J.K. \& Bruno, A.V., 1987, 'CSF analysis and the strategy development process', in D.T. Cleland \& W.R. King (eds.), Strategic planning and management handbook, pp. 333-351, Van Nostrand Reinhold Company, New York.

Leiper, N., 1995, Tourism management, RMIT Press, Melbourne.

Li, S.C.Y., Wong, M.C.S. \& Luk, S.T.K., 2006, 'The importance and performance of key success factors in international joint venture hotels in China', The Chinese Economy 39(5), 83-94. http://dx.doi.org/10.2753/CES1097-1475390606

Lin, S. \& Fu, H., 2012, 'Uncovering critical success factors for business-to-customer electronic commerce in travel agencies', Journal of Travel \& Tourism Marketing 29(6), 566-584. http://dx.doi.org/10.1080/10548408.2012.703034

Locke, M., 2010, 'A framework for conducting a situational analysis of the meetings, incentives, conventions, and exhibitions sector', Journal of Convention \& Event Tourism 11, 209-233. http://dx.doi.org/10.1080/15470148.2010.505473

Lucchetti, V.G. \& Font, X., 2013, 'Community based tourism: Critical success factors', The International Centre for Responsible Tourism 27, 1-20.

Mair, J., 2010, 'Profiling conference delegates using attendance motivations', Journal of Convention \& Event Tourism 11(3), 176-194. http://dx.doi.org/10.1080/15470 148.2010.502032

Manners, B., 2011, 'The critical success factors for managing the visitor experience at a major music event', MA dissertation, NWU, Potchefstroom.

Manners, B., Saayman, M. \& Kruger, M., 2014, 'Managing a live music performance: A supply-side analysis', Acta Commercii 15(1), 1-11.

Marais, M. \& Saayman, M., 2011, 'Key success factors for managing the Robertson Wine Festival', Acta Academia 43(1), 146-166.

Mardani, A., Jusoh, A., Bagheri, M.M. \& Kazemilari, M., 2015, 'A combined hybrid fuzzy multiple criteria decision-making approach to evaluating of QM critical success factors in SME's hotels firms', Prodecia - Social and Behavioral Sciences 172, 786-793.

Maymand, M.M., Farsijani, H. \& Moosavi, S.S.T., 2012, 'Investigation of the key success factors in virtual tourism', Indian Journal of Science and Technology 5(7), 3073-3080.

Mohamed, L.M., 2015, 'Exploring the critical success factors (CSF) and limitations of enterprise resource planning (ERP) systems: The case of Egyptian hotels', Journal of Hospitality \& Management Tourism 6(3), 17-29. http://dx.doi.org/10.5897/
JHMT2015.0137 
Nieh, F. \& Pong, C., 2012, 'Key success factors in catering industry management', Actual Problems of Economics 4, 423-430.

Nieuwenhuis, J., 2008, 'Qualitative research designs and data gathering techniques', in K. Maree (ed.), First steps in research, pp. 69-97, Van Schaik, Hatfield.

Ortigueira, L.C. \& Gomez-Selemeneva, D., 2011, 'Critical success factors of a tourist destination in the Caribbean', Book of Prodecings vol.1 - International Conference on Tourism \& Management Studies 201-214.

Pikkemaat, B. \& Schuckert, M., 2007, Success factors of theme parks - An exploratory study', Tourism: Preliminary Communication 55(2), 197-208.

Ramgulam, N., Raghunandan-Mohammed, K. \& Raghunandan, M., 2012, 'An examination of the economic viability of sustainable business tourism in Trinidad', Review of Business \& Finance Studies 3(2), 69-80.

Rockart, J.F., 1979a, 'Chief executives define their own data needs', Harvard Business Review 57(2), 81-93.

Rockart, J.F., 1979b, 'Chief executives define their own data needs', in J.F. Rockart \& C.V. Bullen (eds.), The rise of managerial computing: The best of the center for information systems research, pp. 207-234, Sloan School of Management, MIT, Cambridge.

Rogers, T., 2003, Conferences and conventions: A global industry, ButterworthHeineman, Boston, MA

Rogers, T., 2013, Conferences and conventions: A global industry, 3rd edn., Routledge, New York.

Rogerson, C.M., 2014, 'Viewpoint: How pro-poor is business tourism in the global South?', International Development Planning Review 36(4), 391-400. http://dx. doi.org/10.3828/idpr.2014.29

Rogerson, C.M., 2015a, 'The uneven geography of business tourism in South Africa', South African Geographical Journal 97(2), 183-202.

Rogerson, C.M. \& Visser, G., 2006, 'International tourist flows and urban tourism in South Africa', Urban Forum 17, 199-213.

Saayman, M., 2009, Hospitality, leisure \& tourism management, 2nd edn., Institute fo Tourism and Leisure Studies, Potchefstroom.

Saayman, M. \& Slabbert, E., 2002, An introduction to conference tourism, Institute fo Tourism and Leisure Studies, Potchefstroom.

Schnitzer, M. \& Strickdorn, M., 2012, 'Key success factors for fan zones (public viewings) covering mega sport events - The case of UEFA EURO 2008TM in Austria', European Journal of Tourism Research 5(1), 19-37.

Smith, K.A. \& Garnham, R., 2006, 'Distribution channels for convention tourism' Journal of Convention \& Event Tourism 8(1), 1-30. http://dx.doi.org/10.1300/ J452v08n01_01

South Africa. Department of Tourism, 2011, National tourism sector strategy: Executive summary, viewed 28 October 2015, from http://www.tourism.gov.za/ AboutNDT/Publications/National\%20Tourism $\% 20$ Sector $\% 20$ Strategy $\% 20$ Executive\%20Summary.pdf
South African National Convention Bureau (SANCB), 2016, viewed 21 January 2016, from http://businessevents.southafrica.net/

Sperstad, J. \& Cecil, A.K., 2011, 'Changing paradigm of meeting management: What does this mean for academia?', Journal of Convention \& Event Tourism 12(4) 313-324. http://dx.doi.org/10.1080/15470148.2011.620600

Statistics South Africa, 2015, Tourism 2015: report no. 03-51-02 (2015), viewed 12 April 2016, from http://www.statssa.gov.za/publications/Report-03-51-02/ Report-03-51-022015.pd

Stetic, S. \& Simicevic, D., 2010, 'Business travellers - An important segment of tourism development in Serbia', in ATLAS (comp.), (ed.), Mass tourism vs niche tourism Cyprus 2010 ATLAS conference 3-5 November Limassol - extended abstracts, pp. 98-105, ATLAS, Arnhem.

Thomas, R., Shaw, G. \& Page, S.J., 2011, 'Understanding small firms in tourism A perspective on research trends and challenges', Tourism Management 32(5), 963-976. http://dx.doi.org/10.1016/j.tourman.2011.02.003

Thompson, J. \& Martin, F., 2005, Strategic management: Awareness \& change, 6th edn., Cengage Learning EMEA, Hampshire.

Tung, J., 2012, 'Key success factors in implementing marketing strategies in tourism industry', Pakistan Journal of Statistics 28(5), 645-651.

Van der Westhuizen, T., 2003, 'Key success factors for developing and managing a guesthouse', MCom dissertation, NWU, Potchefstroom

Van der Westhuizen, T. \& Saayman, M., 2007, 'Key success factors for developing and managing guesthouses: A case of a touristic town', South African Journal for Research in Sport, Physical Education and Recreation 29(2), 121-130. http://dx. doi.org/10.4314/sajrs.v29i2.25974

Wan, Y.K.P., 2011, 'Assessing the strengths and weaknesses of Macao as an attractive meeting and convention destination: Perspectives of key informants', Journal of Convention \& Event Tourism 12, 129-151. http://dx.doi.org/10.1080/15470148. 2011.565704

Wang, S. \& Hung, K., 2015, 'Customer perceptions of critical success factors for guest houses', International Journal of Hospitality Management 48, 92-101. http://dx. doi.org/10.1016/j.ijhm.2015.05.002

Wang, F., Hung, C. \& Li, P.P., 2011, 'A study on the critical success factors of ISO 22000 implementation in the hotel industry', Pakistan Journal of Statistics 27(5), 635-643.

Williams, K. \& Saayman, M., 2013, 'Key success factors of visitors at a jazz festival', South African journal for research in sport', Physical Education and Recreation 35(1), 183-202.

Witbooi, M., Cupido, C. \& Ukpere, W.I., 2011, 'Success factors of entrepreneurial activity in the Overberg region of Western Cape, South Africa', African Journal of Business Management 5(5), 1936-1941.

Yang, Y., 2013, 'Key success factors in catering industry management', International Journal of Academic Research in Business and Social Sciences 3(3), 152-158.

Yeh, S. \& Lin, C., 2012, 'Identifying key success factors of e-learning in travel agents', Pakistan Journal of Statistics 28(5), 565-572. 